\title{
COVID-19 AND AIRLINE REFUNDS: AN ANALYSIS OF FLIGHT PASSENGERS' REVIEWS IN NORTH AMERICA
}

\author{
Oluwaseun Alexander Dada ${ }^{1}$, Sunday Adewale Olaleye ${ }^{2}$, Ismaila T. Sanusi ${ }^{3}$ and George Obaido ${ }^{4}$ \\ ${ }^{1}$ Institute for Molecular Medicine Finland (FIMM), University of Helsinki, Biomedicum 2U, 00290 Helsinki, Finland \\ ${ }^{2}$ Oulu Business School, Department of Marketing, Management and International Business, University of Oulu, Erkki \\ Koiso-Kanttilan katu, 90570 Oulu, Finland \\ ${ }^{3}$ School of Computing, University of Eastern Finland, 80100 Joensuu, Finland \\ ${ }^{4}$ School of Computer Science and Applied Mathematics, University of the Witwatersrand, Johannesburg, South Africa
}

\begin{abstract}
Purpose - This paper analyses the experiences shared by airline passengers during the Covid-19 pandemic especially in relation to refund.

Methodology - A quantitative research approach was adopted. SPSS version 26 was used to analyse the North American airlines rating data through frequency tables, correlation and ANOVA.

Findings - The result reveals that $64 \%$ of the passengers affected were citizens of the United States of America and $23 \%$ Canadians. According to our dataset, Frontier Airlines stood out as the most controversial airline in terms of refund during the Covid-19 pandemic. $99 \%$ of the passengers affected by the refund process during the pandemic flew economy class. Approximately $96 \%$ of the passengers rated the airlines as 'failed' - less than 5 out of 10 . This is an indication that many of the passengers are dissatisfied with the North American airlines' refund process during the Covid-19 pandemic. Only approximately $6 \%$ of the passengers travelled for business purposes while the majority reported travelling for leisure.

Contribution of the study - The study contributes to the growing body of knowledge about the impact of the Covid-19 pandemic on various sectors of the world's economies. It is the first study to the best of our knowledge that examines how flight passengers experienced the refund process of airlines during the Covid-19 crisis. By focusing only on North American airlines, we were able to identify discover some relevant statistics with regards to the affected passengers e.g. citizenships, traveler types, seat types. In addition, the study finds that there were overwhelmingly negative sentiments towards airlines in North America - during the pandemic - by virtue of the manner in which the refund process was handled.
\end{abstract}

\section{KEYWORDS}

Covid-19 Pandemic, Airline Refund, Flight Passengers, North America, Vouchers, Travel Credit

\section{INTRODUCTION}

The outbreak of the coronavirus pandemic has had a significant impact on airlines worldwide - more than at any other time since the 1950s (Passy, 2020). By April 2020, the demand for airline services was down 91\% as millions of flights were cancelled in efforts to mitigate the spread of the virus (Cirium, 2020; Coke-Hamilton, 2020). According to reports, about 300 million passengers were affected by the unexpected cancellations and the majority were denied refund by airlines. In many cases, airlines offered vouchers (or credits for future travel) in lieu of refund - against the wishes of the stranded passengers (BBC, 2020).

In the United States of America, for example, it is estimated that airline companies are deliberately holding back more than $\$ 10$ billion in passengers' cash in the form of vouchers (Passy, 2020). In Europe, it is about $€ 24$ billion (Berti, 2020). It seems that the passengers have a clear case with justified claims against the airlines. Since the airlines failed to provide the service contracted for, a refund should be provided. In reality, however, it seems like a farce - in spite of the fact that there are existing regulations enacted for such a situation (DW, 2020).

Against the above background, this paper analyses the experiences shared by airline passengers during the Covid-19 pandemic especially in relation to refund. The North American continent will be the focus of our investigation as the region has become an epicenter of the pandemic (Worldometers, 2020) having recorded over 13.48 million cases. Furthermore, the region has one of the largest markets for commercial airlines in the world - in terms of passengers and revenue (Abate, Christidis and Purwanto,2020). 
This paper is organized as follows. First, an overview of the literature review will be provided. After that, the research approach used will be explained. This will be followed by a result and discussion section. Finally, conclusions will be drawn.

\section{LITERATURE REVIEW}

Alarmingly, the Covid-19 crisis shows little or no sign of abating as new waves have been recently reported in Europe and the United States of America, resulting in new lockdowns in different cities (Kotoky \& Whitley, 2020). As of November 11, 2020, 1.28 million deaths have been recorded worldwide (Worldometers, 2020). Further, millions of flights have been cancelled largely due to international border restrictions across the globe. The aim of the restrictions is to mitigate the spread of the virus particularly to people at risk. As a consequence, passenger demand has plummeted, thus compelling airlines operators to park their planes rather than flying them (Nunes, 2020).

\subsection{Covid-19 and Airlines}

The decline in the passenger numbers has put the airline industry in serious trouble. According to the International Civil Aviation Organization (ICAO), the global airline industry has lost approximately \$327 billion of passenger revenue. In North America, the loss is about $\$ 78$ billion (ICAO, 2020). The negative impact of the pandemic seems to go beyond the current financial year 2020 as it has been predicted to be down $46 \%$ from 2019's \$838 billion (Kotoky \& Whitley, 2020). Already, 43 commercial airlines have declared bankruptcy and many more are set to follow if no assistance is provided $(\mathrm{Ng}, 2020)$.

In a press release, the Director General of the International Air Transport Association (IATA) stated: "Financially, 2020 will go down as the worst year in the history of aviation. On average, every day of this year will add \$230 million to industry losses ... That's why government financial relief was and remains crucial as airlines burn through cash" (IATA, 2020). To aid the airline industry, various governments around the world have provided financial assistance in different forms. In the United States of America, the industry has received a $\$ 25$ billion bailout package (Nguyen, 2020). In Mexico, Grupo Aeromexico SAB has been granted a \$1 billion bankruptcy loan (Kotoky \& Whitley, 2020).

\subsection{Airlines and Refund}

On social media, passengers complained about their inability to obtain refund for their cancelled flights. It seems airline companies are intentionally making it difficult for their customers (passengers) to access refund. For instance, customers inquiring about refund were made to wait for a relatively long time. On many occasions, the telephone lines were not picked, and emails not replied (Montevago, 2020). There are also allegations that some airline companies have deliberately removed the refund options from their websites. Some airlines have also been accused of selling flight tickets for planes that are never intended to take off (Thiessen, 2020).

Instead of refund, airlines offer travel vouchers. It is projected that airline companies are withholding hundreds of billions of dollars meant to be paid in cash to passengers (Berti, 2020; Passy, 2020). It appears as though refunding passengers for cancelled flights would cause the airlines serious financial upheaval (Dhalla, 2020). Despite the financial distress caused by the Covid-19 pandemic, airlines are still obligated to refund passengers when flights are cancelled. The refusal of airlines to give cash refund to the frustrated passengers has been labelled by experts: unfair, a breach of contract and a direct disregard for regulations. As a consequence, class action cases have been filed by affected passengers against many airlines (Expert Institute, 2020).

\subsection{Online Reviews and Airline Passengers' Experiences}

An airline passenger review is the description and evaluation of the individual's personal experience of using the airline's services. These reviews may consider different aspects of the services provided by the airlines e.g. seat comfort, food and beverages, staff service, and ground service, amongst others. 
Over the years, passenger reviews have moved from Words of Mouth (WoM) shared amongst loved ones to the Internet - now referred to as an electronic Word of Mouth (E-WoM). The advancement in Internet and mobile technologies have made it possible for the rapid implementations of E-WoM.

\subsubsection{Why Do Passengers Use Online Review Platforms?}

Studies have shown that online reviews are more easily distributed than the conventional WoM. The E-WoM makes it easy for ordinary people to share their personal experiences about products online, which can be aggregated as a collective intelligence (O'Reilly, 2005). Therefore, it is not surprising that an increasing number of consumers are now making purchasing decisions based on online reviews (Guernsey, 2000; Hicks et al., 2012). According to a research finding, about $60 \%$ of consumers considered online reviews more valuable than expert reviews (Piller, 1999). According to Parikh et al. (2014), a passenger reads online reviews for the following reasons: 1) reduce the likelihood that a flight ticket purchase will lead to disappointment 2) helps passengers to more quickly sift access relevant information about airlines 3) views expressed by a group is more likely to be true.

\subsubsection{How Can Airline Companies Benefit from Online Reviews?}

Airline reviews offer opportunities and risks to airline companies. One opportunity is that airlines can more easily track passengers' sentiments about their services and products. The reviews can also be leveraged as a strategic platform for a variety of purposes including management activities, e.g. market analysis, branding, customer retention and acquisition (Dellarocas, 2003). The risk associated with online reviews, as far as airlines are concerned, is the fact that the reviews can be seen by everyone and have the power to bring in passengers or drive them away.

\section{METHODOLOGY}

Quantitative methodology is known to be the most suitable approach for statistical analyses (Zupancich and Cristiani, 2020). As our dataset is mostly numerical, we decided to apply statistical analytical approach such as ANOVA, frequency and correlation analyses using SPSS version 26. As such, quantitative methodology was chosen.

\subsection{Data Collection}

The data was extracted from SKYTRAX - an international air transport rating agency. SKYTRAX operates an airline review website that makes it easy for passengers to share their personal flight experiences and express their opinions regarding various airlines' services. SKYTRAX makes efforts to verify passengers' trips by confirming that the trip was actually taken by the reviewer. This is done by inspecting the relevant travel document (e.g. e-ticket, or a boarding pass) with the customer name, depending on the outcome the reviews are tagged: "trip verified" or "unverified".

Since there is no dedicated Application Programming Interface (API) to conduct data extraction on the site, we used Python's BeautifulSoup library to crawl the relevant pages. A total of 138 reviews, containing the words "refund" or "voucher", written between January 2020 and October 2020 were extracted.

\subsection{Data Processing}

Data preprocessing included data cleaning, data segmentation, and removal of unnecessary entries as well as lemmatization. The raw data retrieved from the platform were texts. As part of the preprocessing, irrelevant entries - stop words, HTML identifiers, symbols - were removed. Some specific fields were either renamed for better description purposes (e.g. country was changed to customer's country) or expressed in different formats for analytical purposes (e.g. ratings were changed from fractions to whole numbers). The following are some examples of the extracted passengers' reviews:

"I have 3 flights booked with Air Canada for Oct 2020. Because of the Pandemic I'm not allowed to leave my country. I had a 5 month trip planned starting 1 st Aug that included 21 flights. Air Canada are the only airline not refunding my money back and are profiting from me during the 2020 Pandemic. It's disgraceful and 
unfair. Singapore Airlines, Finnair, Icelandair, Swiss, United, Hawaiian Air, Alaska Air, Delta and American Airlines are refunding back in full. Air Canada are deciding to profit from their customers instead"

"My flight was cancelled because of COVID-19, and they refused to refund me, like many other reviews suggest. I haven't received a credit either. I submitted a complaint to the U.S. Department of Transportation because flights operating in the US are required to refund passengers after cancelling their flights. I also disputed the charges through my credit card company."

"... Interjet cancelled our flights because of COVID-19. They did not send a voucher or any information e-mail. I have been calling Interjet all week from Turkey and no answer at all. One of the worst airlines ever I have seen"

"Worst customer service ever. Rude customer representatives. Never flew they emailed me \& changed my flight \& date then cancelled due to Covid 19. Will not offer refund they decided to keep customers money with hope of them using it in fortune, but I will never use this airline in my life \& I will let everyone know not to."

"Avoid traveling with Silver Airways at any cost! We booked tickets and a flight was cancelled by the airline putting me into a very tough situation. It is almost 3 days I am trying to call them and refund money, spent almost 4 hours in total listening call waiting music - and there is no result. Moreover they use all the possible dirty tricks to push you to give up - hanging up the phone call in the middle, the operator told me one name at the beginning of the call and then another one when I asked who I am speaking with"

"I book a flight with Aeromexico a few weeks ago, now they cancelled the flight 2 weeks from the departure. They refused to refund the money that $i$ pay, that it was a round trip from Chile to Canada, (not cheap), even if they cancelled the flight ... The only option that they give me was an open ticket with them ..."

"I had a flight booked from London to Mexico City on 2nd April, obviously this was cancelled because of the coronavirus pandemic. I have since then spent countless hours on the phone trying to reach them as well as emailing them, they either never reply or just ignore what you say in your email. The Civil Aviation Authority confirmed that a cancelled flight has to be refunded if the passenger wants to, but Aeromexico refuse to offer any refund ..."

\section{RESULTS AND DISCUSSION}

A frequency chart shows the number of times a data value occurs. The frequency tables utilised in this study help to make better sense of the airline's data. It is important to note that one passenger's review is associated with only one airline.

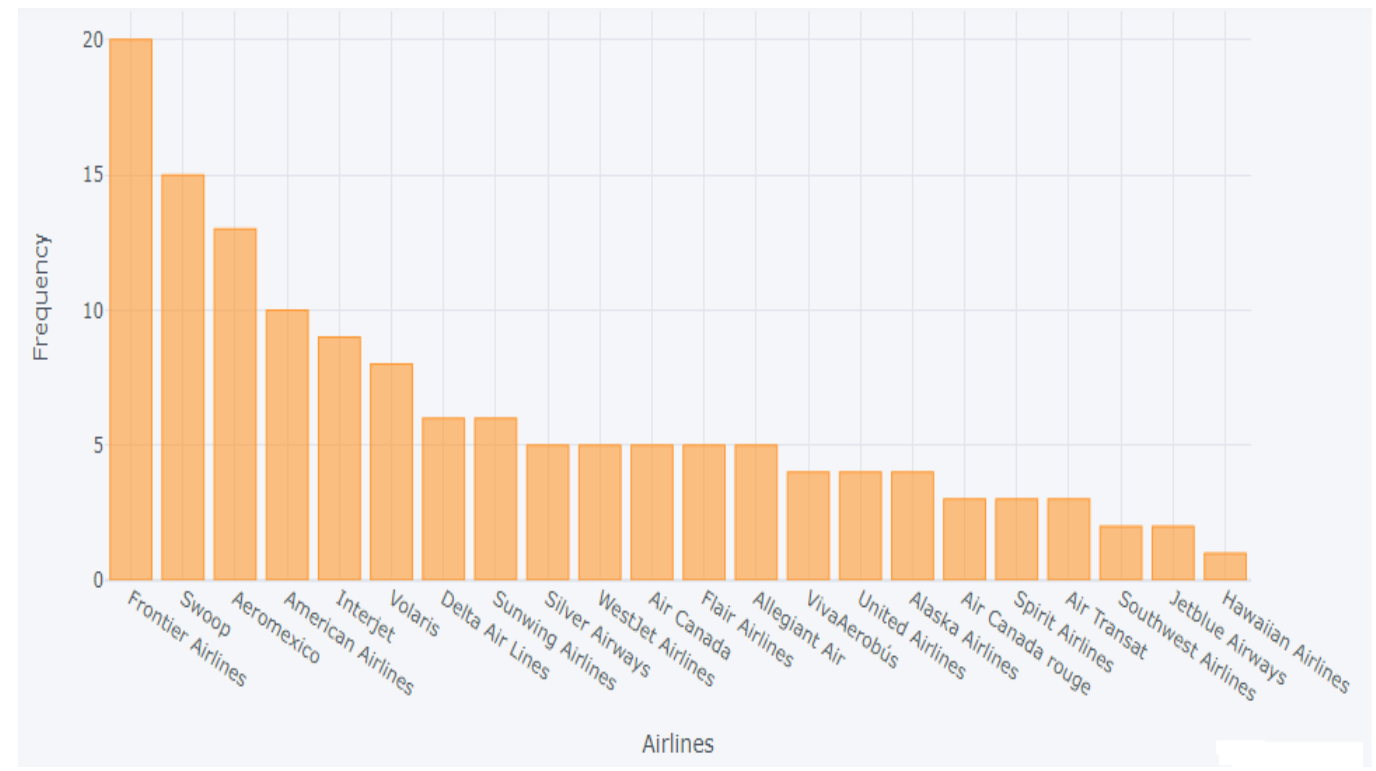

Figure 1. Airline frequency and final rating

Figure 1 shows that the Frontier Airlines has the highest frequency (20). 


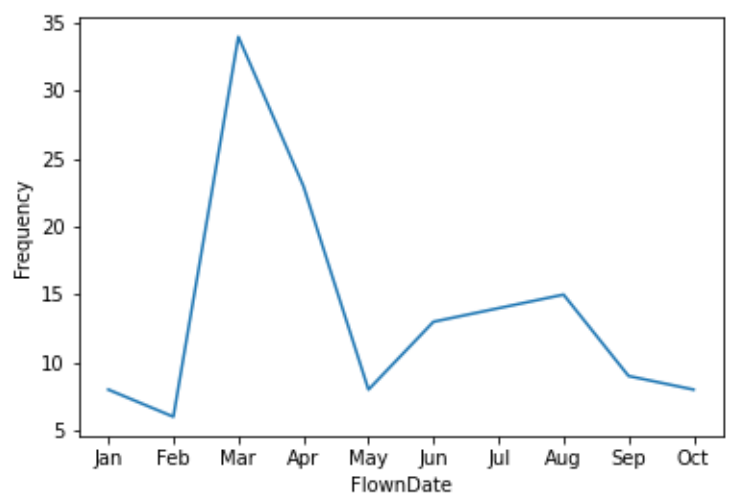

Figure 2. Flight Dates Frequency

The data in Figure 2 shows how Covid-19 has affected the travelling trends. The flying date with the fewest passengers is February 2020 and highest in March 2020.

Analysis of passenger nationality shows the United States tops the list with $(\mathrm{f}=88.63 .8 \%)$. Canada ranks second $(\mathrm{f}=32,23.2 \%)$ and the United Kingdom third $(\mathrm{f}=5,3.6 \%)$. Mexico and Australia had ( $\mathrm{f}=2,1.4 \%)$ while Belgium, Norway, France, Thailand, Italy, Brazil, Turkey, Singapore, and Cayman Islands tallies with $0.7 \%$.

Regarding the seat type, economy class accounts for $\mathrm{f}=136(98.6 \%)$ and both first class and premium economy accounts for $(\mathrm{f}=1,0.7 \%)$. The analysis shows that most of the passengers purchased economy class tickets while a minority bought first class and premium economy seats.

Concerning airlines passenger' type, results show that Family Leisure had the highest frequency with $33.3 \%$, followed by Solo Leisure, 31.2\%, Couple Leisure, 29.7\% and Business the least with 5.8\%. Families travelled more than other types of passengers on North American airlines between January and October 2020.

Trip verification status shows that $58.7 \%$ of trips were verified while $41.3 \%$ were not verified.

A scale 1 to 10 were used by the passengers to rate the airlines ( 1 being the lowest and 10 the highest). Passenger rating shows that the majority of the airlines scored below average rating $(\mathrm{f}=133,96.3 \%)$.

Airline recommendation ratings shows that $(\mathrm{f}=133,96.4 \%)$ did not recommend the North American airlines based on the experience from January to October 2020 while only ( $\mathrm{f}=5,3.6 \%$ ) passengers recommended the airlines. This is an indication that many of the passengers are not happy with the services of the North American airlines during the period under examination.

Correlation between airline name, flown date, and customer's country was calculated; it shows a positive correlation between the flown date, the airline name ( $p$-value $=.027)$ and the customer's country $(p$-value $=.045)$.

Furthermore, a correlation between 'recommend airline', customer rating, final airline rating and customer's country was conducted. The analysis shows that there is a strong correlation between airline recommendation, customer rating $(p$-value $=.000)$ and a weak correlation between recommendation and final airline rating $(p$-value $=.032)$. There is also strong correlation between final airline rating and customer rating $(\mathrm{p}$-value=.009). Furthermore, 'final airline rating' also is weakly correlated with customer's country $(p$-value $=.040)$

We also ran an ANOVA of independent variables and the dependent variable, which shows the factors that are responsible for airline recommendations. Airline name, flown date, customer's country, seat type, passenger type, travelling status, customer rating and final airline rating were used as independent variables and airline recommendation as dependent variable. Out of the eight predictors, only four variables are significant. The results indicates that airline name $F(1,136)=2.58, p=<0.01$, passengers' type $\mathrm{F}(1,136)=3.32, \mathrm{p}=<0.01$, customer's rating $\mathrm{F}(1,136)=1314.86, \mathrm{p}=<0.01$, and the final airline rating $\mathrm{F}(1,136)=4.70, \mathrm{p}=<0.01$ determine airline recommendations.

According to Uğur \& Akbiyık, (2020), the tourism industry was one of the world's greatest markets until the Covid-19 pandemic. Monmousseau et. al. (2020) also stated that the pandemic has had a significant impact on the air transportation system worldwide. Several research studies have emerged with a focus on airline- and passenger-related issues as a result of the pandemic. For instance, a study by Uğur \& Akb1yık (2020) presented the reactions of passengers during the pandemic and Forsyth, Guiomard, \& Niemeier (2020) analyzed the price responses of airports to a demand collapse. Studies also analyzed the effect of the travel restriction measures during Covid-19 pandemic and airline reactions to the Covid-19 crisis (Monmousseau et. al., 2020; Albers, $\&$ Rundshagen, 2020). This study, however, is concerned with airline refund based on the experiences of flight passengers. Utilizing data from an airline review website, North American airlines rating data were analyzed 
through frequency tables, correlation and ANOVA. Analyses were made based on the following metrics; Airline frequency and final ratings, Airline Flown Dates, Airline Customer's Country, Airline Seat Type, Airline Passengers Type, Trip Status, Passengers Rating, and Airline Recommendation.

The result shows the Airlines frequency which represents the number of passengers that travelled with a particular airline and subsequently wrote a review about their experience in relation to refund. Frontier Airlines came through as the most frequently reviewed airline. This is consistent with reports in the media. In the United States, the airline was been accused - more than any of its competitor - of "deceptive and unfair" practices such as issuing "unusable" vouchers in lieu of cash refund (Parker \& Green, 2020); Svaldi, 2020). Several class action lawsuits were also filed against the airline by passengers (Sortor, 2020). In addition, a Colorado Attorney-General (Phil Weiser) also officially requested investigation into the airline's handling of refund during the crisis (Padilla, 2020; Svaldi, 2020). On the other hand, Hawaiian Airlines has the lowest frequency (1); in other words, it was the least talked about in terms of refund during the pandemic. The airline scored one of the best ratings. This result confirms that Hawaiian Airlines seems to be more empathic and more favorable in light of its introduction of a refund policy that makes it easy for all passengers to change flights tickets purchased during the pandemic - given one year window of opportunity - and it seems the rebooked trip may be used on or before May 2022 (Hawaiian Airlines, 2020); Tripadvisor, 2020).

The results have also shown that despite increased border restrictions to mitigate the spread of the virus, there was still movement of people across borders. The month of March 2020 was the busiest in terms of air travel, the second was April 2020. This is in line with national travel restrictions implemented in various countries. In Canada, these restrictions took effect on the March 13th (Ghosh, 2020) and by the 1st of April 2020 almost all major commercial airlines had completely stopped flying - mostly due to international border closures (Pallini, 2020). With respect to the airline customer's country, our dataset also shows that the United States topped the list of customers travelling by plane during the pandemic. We also observed that value, comfort and best service delivery seems not to be the passengers' priority during Covid-19 pandemic as they most frequently opted for economy class seat type. It can then be deduced that the utmost priority of the airline customers is to get a flight to convey them to their destinations inexpensively as both the first class and premium economy has very low patronage.

The airline passengers' type showed that leisure is the reason for most plane travel among North Americans during January and October 2020. Based on the reviews, leisure is categorized by customers into three groups namely: family leisure, solo leisure and couple leisure. Family leisure is described as the time spent together as a family in free time or recreational activities (McCabe, 2015). Solo leisure means spending significant time alone while couple leisure is described by Ward, et. al (2014) as time spent together by couples while they engage in recreational activities. Most passengers during the period were families followed by individuals that embark on solo leisure and closely followed by couples. The reason for the highest frequency of leisure is a bit unclear especially considering the fact that the pandemic had made it mandatory for everyone to maintain self-isolation or social distance as much as possible. Business passengers' account for only about $6 \%$, which would be expected since businesses, activities and transactions have been operated partially and virtually. The verification status of the reviewers is also shown with the aim to confirm the passengers actually took the trip they commented about. The result shows most of the reviewers of the trips were verified according to SKYTRAX where the data was extracted. The passengers rated the North American airlines; findings show that they were rated very low during the period of review. Similarly, almost all passengers did not recommend the North American airlines based on their experiences within the review period. We can infer that the passengers at the time were unhappy with the services provided by the airlines regarding refund, hence the low ratings and non-recommendation.

Additionally, this study finds a correlation between airline name, flown date, and customer's country. The analysis shows there is a positive correlation between the flown date, the airline name and the customer's country. This finding negates the study of Gerstman, (2014), who found weak correlation among the variables. The reason for the difference may be the choice of the selected airline, flown date or even the customer's country of origin. Relatedly, the correlation between recommendation, customer rating, final airline rating and customer's country was analysed. The analysis shows there is a strong correlation between airline recommendation and customer rating. There is also a strong correlation between final airline rating and customer rating. However, final airline ratings correlate weakly with the customer's country. This simply shows that the final rating of the airlines is not associated or influenced by the country the customer comes from. Lastly, this study has provided the results of an ANOVA of independent variables (airline name, flown date, customer's country, seat type, passenger type, travelling status, customer rating and final airline rating) and dependent variable (airline recommendation). Of the eight variables, four were found to be significant of the eight predictors. The analysis shows the factors that determine airline recommendations include airline name, passengers' type, customer rating and the final airline rating. These findings evince the importance of the airline 
name as well as passengers' type (leisure or business), the ratings of customers and the final airline rating in determining recommendation of airlines.

Our findings provide a greater understanding of passengers' reviews on the issue of airfare refund during the pandemic. Lessons from managing passengers' reviews are essential to gaining trust in the airline industry. As advised by Chesbrough (2020), openness is key to gaining trust, and this is crucial to the airline industry. Some suggested best practices that key stakeholders in the airline industry could apply during the pandemic and beyond are: providing passengers with a choice between refund and vouchers, ensuring clarity on getting refund, government legislation must be enforced throughout the refund process and promoting stronger passenger's rights.

\section{CONCLUSION}

The Covid-19 pandemic has dramatically disrupted many businesses all over the world, especially the global airline industry. Since the outbreak of the pandemic, passengers' requests for airfare refund has increased exponentially due to flights cancellations. The majority of airline carriers, especially those within North America, have offered vouchers to passengers for future travel in place of refund against passenger wishes, thus leading to increased frustrations. This paper has detailed the experiences shared by airline passengers' requests for refund of flights cancelled during the Covid-19 pandemic. Our analysis has shown that about $96 \%$ of the passengers rated the airlines as 'failed' - i.e. less than 5, on a scale of 1 to 10 . This is an indication that many of the passengers are dissatisfied with the North American airlines' refund process during the Covid-19 pandemic. To cushion the effects of Covid-19 on passengers, we believe that airlines carriers should adopt better customer-centric strategies instead of the enforced approach of offering travel vouchers in lieu of refund.

\section{STUDY LIMITATIONS AND FUTURE RESEARCH}

The following are some of the limitations encountered. First, given that Covid-19 is a timely occurrence, only 138 online reviews were available as at the time this study was conducted. This is a relatively small sample. However, it also presents opportunity for future researchers to gather more data whilst extending this research. Second, the range of this research is limited to North America. In the future, similar investigation may be conducted for other regions of the world. Third, it would be interesting to carry out a research that compares the refund process and policies of North American airlines before, during, and after Covid-19. Lastly, there is a need for a more comprehensive look at a more generalizable insights about refund strategies adopted by companies across various industries during the pandemic.

\section{REFERENCES}

Abate, M., Christidis, P., \& Purwanto, A. J. (2020). Government support to airlines in the aftermath of the Covid-19 pandemic. Journal of Air Transport Management, 89 (1) https://doi.org/10.1016/j.jairtraman.2020.101931.

Albers, S., \& Rundshagen, V. (2020). European airlines' strategic responses to the Covid-19 pandemic (January-May 2020). Journal of air transport management, 87, 101863.

BBC. (2020, November 11). Coronavirus: Airlines warned over passenger refund rights. Retrieved from https://www.bbc.com/news/business-52606374

Berti, A. (2020, November 11). Covid-19 and airline refund: does the system need to change? Retrieved from https://www.airport-technology.com/features/Covid-19-airline-refund/

Cirium. (2020, November 11). ICAO predicts 1.2 billion fewer air travelers by September. Retrieved from https://www.flightglobal.com/airlines/icao-predicts-12-billion-fewer-air-travellers-by-september/138032.article

Coke-Hamilton, P. (2020, November 11). Airlines must respect consumers' rights. Retrieved from https://unctad.org/news/airlines-must-respect-consumers-rights

Dhalla, R. (2020, November 11). Airlines should rethink their refusal to refund passengers during Covid-19. Retrieved from https://theconversation.com/airlines-should-rethink-their-refusal-to-refund-passengers-during-Covid-19-140380

DW. (2020, November 11). Coronavirus crisis: Airlines make it difficult to get refund for canceled flights. Retrieved from https://www.dw.com/en/coronavirus-how-to-get-a-refund-for-a-canceled-european-flight/a-54528044

Expertinstitute. (2020, November 11). Covid-19 Airline Refund Lawsuits: Litigation Guide. Retrieved from https:/www.expertinstitute.com/litigation-guides/Covid-19-airline-refund-lawsuits/ 
Forsyth, P., Guiomard, C., \& Niemeier, H. M. (2020). Covid-19, the collapse in passenger demand and airport charges. Journal of air transport management, 89, 101932.

IATA. (2020, November 11). Industry Losses to Top $\$ 84$ Billion in 2020. Retrieved from https://www.iata.org/en/pressroom/pr/2020-06-09-01/

ICAO. (2020). Effects of Novel Coronavirus (Covid-19) on Civil Aviation: Economic Impact Analysis. Montréal, Canada: ICAO.

Gerstman, B. B. (2014). Basic biostatistics. Jones \& Bartlett Learning, LLC.

Ghosh, I. (2020, November 14). This chart shows how airlines are being grounded by Covid-19. Retrieved from https://www.weforum.org/agenda/2020/03/this-chart-shows-how-airlines-are-being-grounded-by-Covid-19/

Hawaiian Airlines. (2020, November 14). Rule 24: Refund. Retrieved from https://www.hawaiianairlines.com/legal/domestic-contract-of-carriage/rule-24

Kotoky, A., \& Whitley, A. (2020, November 11). These are the airlines teetering on the brink of Covid-19 ruin. Retrieved from https://www.japantimes.co.jp/news/2020/11/02/business/corporate-business/airlines-coronavirus/

McCabe, S. (2015). Family leisure, opening a window on the meaning of family. Annals of Leisure Research, Vol. 18, 2: Special issue on children, families and leisure, part 1.

Monmousseau, P., Marzuoli, A., Feron, E., \& Delahaye, D. (2020). Impact of Covid-19 on passengers and airlines from passenger measurements: Managing customer satisfaction while putting the US Air Transportation System to sleep. Transportation Research Interdisciplinary Perspectives, 7, 100179.

Montevago, J. (2020, November 11). Expedia Travel Clients Experience Chaos with Covid-19 Disruptions. Retrieved from https://www.travelmarketreport.com/articles/Expedia-Travel-Clients-Experience-Chaos-with-Covid-19-Disruptions

$\mathrm{Ng}$, A. (2020, November 11). Over 40 airlines have failed so far this year - and more are set to come. Retrieved from https://www.cnbc.com/2020/10/08/over-40-airlines-have-failed-in-2020-so-far-and-more-are-set-to-come.html

Nguyen, T. (2020, November 11). Why is it so hard to get a flight refund? Retrieved from https://www.vox.com/thegoods/2020/5/22/21266706/canceled-flight-refund-covid-airlines

Nunes, A. (2020, November 7). How Covid-19 will change air travel as we know it. Retrieved from https://www.bbc.com/future/article/20200709-how-Covid-19-will-change-air-travel-as-we-know-it

Padilla, A. (2020, November 14). Colorado Attorney General Wants Federal Investigation into Frontier Airlines After 'Hundreds' of Complaints. Retrieved from https://denver.cbslocal.com/2020/10/04/colorado-attorney-general-federalinvestigation-into-frontier-airlines-hundreds-complaints/

Pallini, T. (2020, November 14). 64 global airlines have completely stopped flying scheduled flights due to travel bans, airspace closures, and low demand for travel — see the full list. Retrieved from https://www.businessinsider.com/coronavirus-global-airlines-stopping-flights-suspending-operations-2020$3 ? \mathrm{r}=\mathrm{US} \& \mathrm{IR}=\mathrm{T}$

Parker, L., \& Green, R. (2020, November 14). Airline Frustration: Passengers Face New Headaches Trying to Use Travel Credit. Retrieved from https://www.nbcchicago.com/consumer/frontier-airlines-frustration-passengers-face-newheadaches-trying-to-use-travel-credit/2304977/

Passy, J. (2020, May 11). Airlines are issuing billions of dollars in vouchers - but can you still get a cash refund for coronavirus-related flight cancellations? Retrieved from https://www.marketwatch.com/story/airlines-are-sitting-onover-10-billion-in-vouchers-as-they-refuse-refund-for-coronavirus-cancellations-democratic-senators-say-2020-04-17

Svaldi, A. (2020, November 14). Colorado attorney general calls for federal investigation into Frontier Airlines. Retrieved from https://www.denverpost.com/2020/09/02/colorado-attorney-general-federal-investigation-frontier-airlines/

Sortor, E. (2020, November 14). Frontier Airlines Class Action Seeks Covid-19 Refund. Retrieved from https://topclassactions.com/coronavirus-Covid-19/frontier-airlines-class-action-seeks-Covid-19-refund/

Thiessen, T. (2020, November 11). Beware Airlines Selling Tickets for Flights That Will Never Take Off. Retrieved from https://www.forbes.com/sites/tamarathiessen/2020/04/28/airlines-selling-tickets-for-flights-that-wont$\mathrm{fly} / ? \mathrm{sh}=96 \mathrm{f} 75 \mathrm{e} 391 \mathrm{c} 09$

Tripadvisor. (2020, November 14). Hawaiian Airlines Covid 19 Waiver. Retrieved from https:/www.tripadvisor.com/ShowTopic-g1-i10702-k13332525-Hawaiian_Airlines_Covid_19_WaiverAir Travel.html

Uğur, N. G., \& Akbıyık, A. (2020). Impacts of Covid-19 on global tourism industry: A cross-regional comparison. Tourism Management Perspectives, 36, 100744.

U.S Department of Transportation. (2020, November 11). Refund. Retrieved from https://www.transportation.gov/individuals/aviation-consumer-protection/refund

Ward, P.J., Barney, K.W., Lundberg, N.R. and Zabriskie, R.B. (2014). A critical examination of couple lesisure and the application of the core and balance model. Journal of Leisure Research, vol. 46(5), 593-611.

Worldometers. (2020, November 11). Coronavirus cases. Retrieved from https://www.worldometers.info/coronavirus/

Zupancich, A., \& Cristiani, E. (2020). Functional analysis of sandstone ground stone tools: arguments for a qualitative and quantitative synergetic approach. Scientific reports, 10(1), 1-13. 